\title{
Development of the World Market of Services in the Context of Globalization: Institutional and Network Approaches
}

\author{
Innessa Efremenko ${ }^{1} \&$ Tatiana Panasenkova ${ }^{1}$ \\ ${ }^{1}$ Rostov State University of Economic, Rostov-on-Don, Russia \\ Correspondence: Innessa Efremenko, Bolshaya Sadovaya str., 69., 344002, Rostov-on-Don, Russia. Tel: \\ 7-989-511-1425. E-mail: efremenko@yandex.ru
}

Received: July 23, 2014 Accepted: August 20, 2014 Online Published: November 14, 2014

doi:10.5539/ass.v10n23p161

URL: http://dx.doi.org/10.5539/ass.v10n23p161

\begin{abstract}
The general trend of economic development in the last century is the transformation of the industrial economy in the post-industrial or service economy that is due to a number of factors - innovation in the agricultural sector and industrial production, the complication of institutional, instrumental and technical and technological frameworks of national economies, changes in the system of social needs, growth of social activity of population. In this regard, the study of the dynamics and trends of the global services sector as a whole and its segments in particular is an important task in both the theoretical and practical terms.

Transnationalization of global hospitality market determines the links between its individual segments and economic system in general. These links are evident not only between market participants, but also between the segments of global goods and capital market. As a result, transnationalization acts as stabilizing mechanism for the world economy in general and the global hospitality market in particular.
\end{abstract}

Keywords: institutes, globalization, market, services

\section{Introduction}

\subsection{Introduce the Problem}

The objectives of this study are: 1) to determine the role of the service sector in the world of modern global economy; 2) to analyze the structure of the global services sector; 3) to investigate the relationship of theoretical approaches to the analysis of the transnationalization of the world market.

We are going to define the role of the service sector in the world economy based on the analysis of statistical data of the World Bank on the growth and structure of the global GDP.

According to the World Bank, the growth rate of world GDP in 2012 amounted to 2\%, less than this value, the growth rate was only in $2008-1.7 \%$ and $\%$ in 2009 (World Development Indicators, 2013). This is explained by the post-crisis economic stagnation of the world economy. In turn, the growth rate of global services sector also reflect the impact of the global crisis, the decline was $0.5 \%$.

Analysis of the ratio of the growth rate of world GDP changes and added value produced in the global services sector leads to the conclusion about the coincidence of such changes. The trajectory of growth of added value produced in the global services sector is almost identical to the trajectory of global GDP growth, although the latter does not contain inherent sharp downturns (e.g. 2009). In our opinion, this indicates a significant impact of the global service sector on growth rates of world GDP.

The relationship between the growth in the services sector and the global GDP are due to the high specific gravity, which takes the service sector in the structure of world GDP, overshadowing the production of industrial goods and primary sector. It should be noted, that for 2003-2010, the share of services in world GDP rose from $67.9 \%$ to $69.9 \%$.

\subsection{Explore Importance of the Problem}

These facts being taken into consideration, we can conclude that during the crisis the slowing of global GDP growth was mainly due to a fall in the growth rate of primary and secondary sectors of the world economy, while the global services sector showed greater stability. In our opinion, this indicates high significance of the added value created in the global services sector to global GDP. In addition, the stability of the service sector to the 
crisis, as we assume, may be due to the basic laws of its development, marked by many researchers (Korolyov, 2003; Sohrokov, 2011).

This pattern is the development of the services sector through integration with the production of industrial goods, and not isolation from the secondary sector of the economy, the depth of such integration largely determining the efficiency of the economy.

However, the development of the service sector due to its diversified industrial structure allows different branches become services sector's growth engines in different time periods. Thus, with the development of innovation traditional services (trade, transport) concede leadership to telecommunications and high technology services.

\subsection{Statistics and Data Analysis}

To investigate the structure of the world service sector we will examine the dynamics of exports and imports of services by industries, 2005-2012.

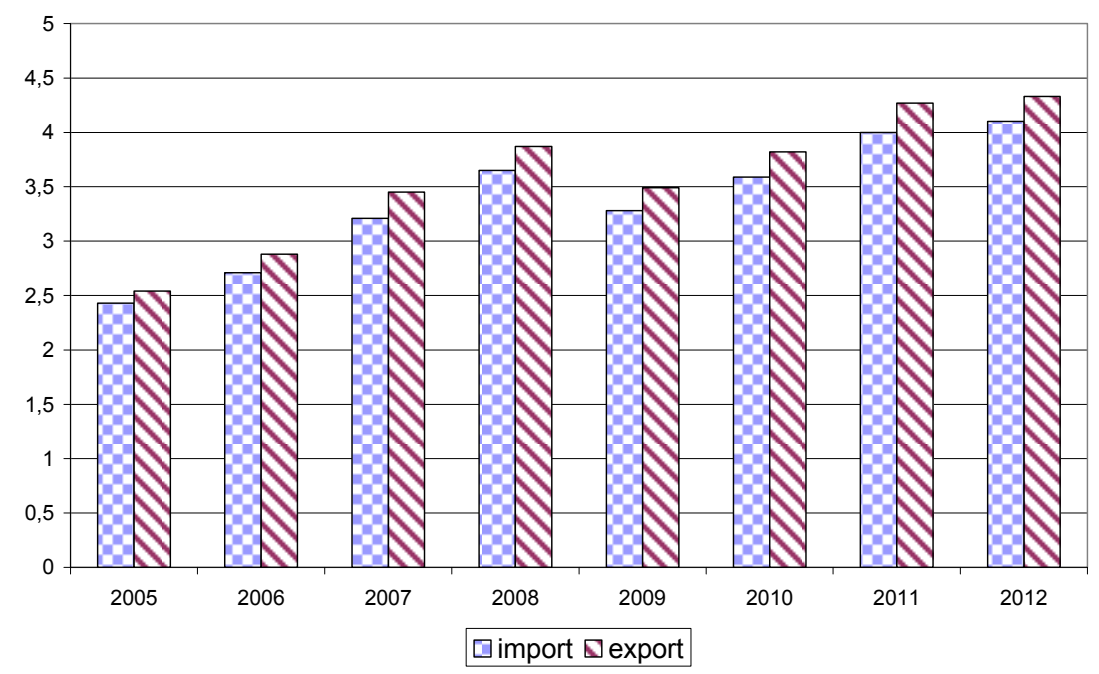

Figure 1. Dynamics of global imports and exports of services volume and in 2005-2012., Trillion dollars (World Development Indicators, 2013)

Figure 1 shows the comparative dynamics in world exports and imports of services for 7 years. Its study allows us to draw two important conclusions: 1) despite the fragile state of the global economy in this period, the volume of both export and import of services grew (world imports of services increased from 2.43 trillion dollars in 2005 to 4.1 trillion dollars in 2012 year, or $68 \%$, while world exports of services increased from 2.54 trillion dollars in 2005 to 4.33 trillion dollars in 2012, or 70\%), while growth rates were close in value ; 2 ) for the entire period 2005-2007 the export of services was ahead of imports of services. The magnitude of the surplus in the global services sector had gradually increased from 0.11 trillion dollars in 2005 to 0.23 trillion dollars in 2012 (maximum value - 0.27 trillion dollars in 2011) (Table 1).

Table 1. The dynamics of the global balance of exports and imports of services in 2005-2012., Trillion dollars

\begin{tabular}{lllllllll}
\hline Years & 2005 & 2006 & 2007 & 2008 & 2009 & 2010 & 2011 & 2012 \\
\hline Balance & 0.11 & 0.17 & 0.24 & 0.22 & 0.21 & 0.23 & 0.27 & 0.23 \\
\hline
\end{tabular}

Source: calculated and compiled by the author based on the World Development Indicators 2013.

Combined with increasing share of services in world GDP growing volume of world exports and imports of services, as well as an increase in surplus allow us to conclude that there is expansion of cross-border trade with services. 
In the sectoral structure of world exports of services in 2005-2012 computer, communications and other services are leading - their share increased from $41.6 \%$ in the volume of commercial services in 2005 to $44 \%$ in 2012 , or by $2.4 \%$ (World Development Indicators, 2013).

Tourist services (services to travelers) occupy the second place in the sectoral structure of world exports of services. However, the share of tourism services in global exports reduced - during the period of 2005-2012 it decreased by $1.8 \%$. Transportation services show a negative trend, occupying the third place in global exports.

Their share in 2005 was $24.7 \%$ and in 2012 decreased to $22.3 \%$, or $2.4 \%$. There is also an increase of the share of insurance and financial services in world exports of services - during the period under consideration, their share increased by $1.6 \%$ and amounted to $7.5 \%$ in 2012 .

Thus, the sectoral structure of exports of services is not fundamentally changed over the years 2005-2012, but changing trends are present - there is a growing share of computer, communications, insurance and financial services whilst the share of tourist and transportation services is going down.

Computer, communications and other services are also leading in the sectoral structure of world imports of services in the years $2005-2012$ as their share increased from $36.6 \%$ in the volume of commercial services in 2005 to $40.2 \%$ in 2012, or $3.6 \%$. Transport services occupy the second place in the industrial structure of world imports of services. However, the share of transport services in global imports is reducing - for the period 2005-2012 it decreased by $2.5 \%$ travel services show a negative trend in global imports occupying the third place. Their share in 2005 was $27.4 \%$ and in 2012 decreased to $24.7 \%$, or $2.7 \%$. In turn, the share of services in global imports of insurance and financial services increased during the studied period, their share increased by $1.5 \%$ and amounted to $8.2 \%$ in 2012 .

Thus, the sectoral structure of world imports of services is not fundamentally changed over the years 2005-2012., but present trends can be identified as growing share of computer, communications, insurance and financial services by reducing the share of tourist and transportation services.

An analysis of the sectoral structure of world exports and imports of services, we note the same trends: an increase in the proportion of computer, communications, insurance and financial services, while reducing the share of tourist and transportation services.

\section{Method}

\subsection{Identify Subsections}

Globalization of the world market is accompanied by a change in its institutional structure, growth potential and its functional significance in the economic system. The study of economic development in this context is identified as an analysis of innovation institutions, those institutional innovations that reduce transaction costs and production costs compared to alternative institutional structures.

It is a study of innovation institutions, which makes it possible to conclude more complex transactions by reducing transaction (and production) costs of these exchanges (North, 1994).

The solution to this theoretical problem allows basing on institutional dynamics and its management anticipate and adjust the economic development and economic growth.

International market of services has emerged as a response to the demand from the increasingly developing transnational corporations (TNCs) operating under uniform or similar standards across countries. Factors in the development of the international market for services as an alternative to national markets are weak regulation; ability to optimize taxation; reducing costs for consumers - TNK in various national markets; integration of the European market; equality institutional conditions for all market participants. These factors influence the logic of formation and development of the world market (Alifanova, 2006).

\subsection{Institutional Approaches}

Thus, in the context of globalization institutional structure of the world market of services is changing, its functional capacity is increasing, and as a consequence its importance in the economic system as a whole. As a result the analysis of the global hotel market, as part of the world market of services, can be seen as an analysis of innovation institutions. These innovations within the tenets of institutional theory should reduce the level of transactional costs and production costs, including services, compared with pre-existing institutions.

Classification of institutions by D. North presents the following groups:

- institutions that have directly decreased transaction (and production) costs level;

- institutions assuring performance of contract obligations. 
Institutions directly decreasing transaction costs are divided into three types of innovation: adaptively efficient institutions (reducing the exchange costs), innovations directly cutting transaction costs and those transforming uncertainty into risk.

In his research D. North notes integrating structures (TNC), serving as a risk-sharing facility.

An ability to internalize relations and communications within international service market in its intracorporate relationships determines dynamic development of financial industrial groups and other integrated corporate structures. During the crises this TNC's ability becomes the main condition of stabilization and growth within economic activity of the integrated companies.

Showing soundness during the crises, such companies become "automatic stabilizers" of economic system, coincidently maintaining the market strength considering that abovementioned companies, their fellow subsidiaries, corporate units and affiliated business entities operate on this market. Indeed, they are able to overcome the negative effects of numerous financial constraints, institutional norms restricting their growth (Alifanova, 2005).

In their studies, Mihir A. Desai, C.Fritz Foley, Kristin J. Forbes (Desai, Fritz, Forbes, 2004) confirm the conclusions on the differential effects of financial constraints regarding TNC and local enterprises growth. Co-investigators prove that affiliate branches of U.S. multinationals unlike local enterprises are willing to overcome limitations of emerging markets imposed by national regulations or caused by economic crises.

Thus, we can conclude that the role of TNCs on the global hospitality market can be performed through the role of risk-sharing facility. During the crises local enterprises have insufficient investment opportunities compared to the integrated structures. However, branches and subsidiaries access to TNC's investment resources removes these restrictions. In addition, both during the crises and renewal period (recession), parent companies may perform investment inflows in their branches.

These results show a special role of foreign direct investments within the tool of integrated systems on emerging markets, where TNCs lead their economic activities during the financial crises, while local enterprises are more limited in their growth opportunities.

Integrated International Hotel Chains are the agents of globalization processes, while their structure and interaction act as automatic stabilizers, able to adapt new changes in globalization process. Thus, the existing network structure of the world market is supported by integrated business units and integrated mechanism of protection against instability. The ability of integrated companies to show soundness during the crises and act as economy stabilization facility within internationalization of relations declares itself in national markets' post-crisis development peculiarities.

Another direction of innovation development, turning uncertainty into risk, is a settlement of the major market participants' interests, foremost those of national economies and transnational corporations, and the equalization of market and nonmarket institutions' activity standards.

The purpose of these innovations is to reduce the risk of moral hazard.

The reduction of this type of risk is associated with the presence of information asymmetry and dissimilarity of business environment in various segments of the global hospitality market. The equalization of these conditions due to the introduction of international standards of performance reduces information asymmetry and the level of moral hazard. In the context of world economy's polycentric development and regional competition of world's major centers (North America, Southeast Asia and Western Europe) the assumptions of regional fragmentation on the world market are being developed. This process generated by globalization is one of the factors deterring its rate of growth, which leads to the formation of the world market's polycentric structure.

This leads to the formation of highly integrated structures and their networking cooperation based on TNCs as a special defense mechanism, countering the challenges of globalization.

Highly integrated structures and transnationalization of hospitality world market builds up a multilevel relations architecture, which in turn strengthens the system in general and reduces the disadvantages of communication system principles (market and hierarchy). This architecture is marked by the fractality and repeats at the global, regional and national levels.

Transnationalization of hospitality market is condition upon TNC's ability to integrate relations and links of the market in its intracorporate relationship system. During periods of growth, this mechanism is alternative and complementing with a capital flow mechanism; during the crises it forms the basis of stabilization and growth of integrated companies' economic activity. 
Showing soundness during the crises, such companies become "automatic stabilizers" of economic system, coincidently maintaining the market strength considering that abovementioned companies, their fellow subsidiaries, corporate units and affiliated business entities operate on this market. Indeed, they are able to overcome the negative effects of numerous financial constraints, institutional norms restricting their growth (Alifanova, 2005).

According to analysis of transnationalization process and its impact on the world hospitality market globalization within the institutional approach, we conclude that TNCs increasing role is determined by the possibility of their dominant role on the local domestic markets from the perspective of their income capitalization and market statement in general. This is manifested in the fact that unlike local companies facing financial difficulties during the crises, parent TNC entities can hold financial investments in their subsidiaries.

Thus a significant role of FDI becomes evident through the mechanism of transnational companies on emerging markets, where integrated structures carry out their economic activities during the financial crises, while local enterprises are still more limited in their growth opportunities.

Modern economic science increasingly conducts researches aimed to solve the problem of integrated network associations' cross-country analysis.

\subsection{Comparison of Institutional and Network Approaches}

The most appropriate to modern realities results are obtained using the tools and basic principles of the network approach.

In his studies, D. Struck explains the phenomenon of industry conversion (during the crisis, with inoperative formal institutions) into loss withstand structure (Stark, 1996).

Network approach is widely used in the study of the features of market development peculiarities (White, 1981).

Therewith researchers conclude that the use of network approach allows studying phenomena with the nature that can't be derived from institutions' reasoning.

Economic theory determines network as a structure using foremost the economies of scale.

In this case, the network organization is an intermediate form between market and hierarchical interaction of local participants - actors. Intracompany collaboration helps to reduce transaction costs associated with information gaining, control, etc (Williamson, 1999). Thus, the basic idea of the network approach application is the search of the most effective ways to reduce transaction costs.

As part of the network approach, researchers aim to study the ways to increase economic system elasticity. Based on this research the objects of research within the network approach may be as follows:

- labor markets: the most significant studies were conducted by Granovetter, M. (Granovetter' 2002);

- stock markets and exchange activities, studied by W. Baker and his co-investigators. Scientists analyze informal relationships between professional participants of the securities market and their impact on price determination (Baker, 1984);

- other market structures, where market is considered as community of similar products' producers. Major works were presented by H. White, R. Burt, etc (White, 1981).

\section{Results}

Thus, we see the possibility to use a network approach performance while studying the features of integrated TNC networking structures on the global hospitality market.

In this context, we consider it necessary to define the parameters that characterize the network units. These parameters are appropriate to be used as criteria for evaluating the network structures formation features at different levels of the global hospitality market.

Oleinik A. identifies the following settings of network entities (Oleinik, 2003):

- network density that is measured by the number of agents and connections between them;

- degree of network centralization that is determined by the extent to which agents are grouped around head center;

- network homogeneity (degree of homogeneity / heterogeneity);

- link strength;

- link tightness that is measured by the number of contacts or transactions over a certain period of time; 
- link sufficiency;

- link stability.

These parameters characterize the network unit as a form of communication with a certain configuration, determining the structure of economic agents.

In this study, we side to complement the results and conclusions obtained using the institutional approach as well as conclusions within a network approach. The basic principles and the content of these approaches are summarized in Table 1.

Table 1. Basic concepts of network and institutional approaches

\begin{tabular}{|c|c|c|}
\hline & Network approach & Institutional approach \\
\hline Basic concepts & Resource flows; principle & Transaction costs; rights \\
\hline & Principle of interdependence; positioning & Right of property; order coordination \\
\hline $\begin{array}{l}\text { Condition of } \\
\text { structure forming }\end{array}$ & $\begin{array}{l}\text { Common field of activity, active stand of } \\
\text { participants. Practice coordination based } \\
\text { on interpersonal relations principles. } \\
\text { Mimicry, practice reproduction. }\end{array}$ & $\begin{array}{l}\text { Common stage of activities, interaction } \\
\text { control mechanisms. Forming and } \\
\text { structuring of common activity fields, order } \\
\text { coordination }\end{array}$ \\
\hline $\begin{array}{l}\text { Mechanism needed } \\
\text { for structure } \\
\text { operation }\end{array}$ & $\begin{array}{l}\text { Social intercourse, communication } \\
\text { network, data channels }\end{array}$ & $\begin{array}{l}\text { Mutual actions; social skills; adoption of } \\
\text { operating principle, control concept, } \\
\text { equivalence }\end{array}$ \\
\hline $\begin{array}{l}\text { Basic functions of } \\
\text { structures }\end{array}$ & $\begin{array}{l}\text { Reduction of uncertainty and opportunism, } \\
\text { improvement of adaptive capacities }\end{array}$ & $\begin{array}{l}\text { Solving the problems of corporate action } \\
\text { (strategic alignment of } \\
\text { actors-maximizators), predictability, } \\
\text { actions commonality. }\end{array}$ \\
\hline Main issue & Communication channels support & $\begin{array}{c}\text { Order legitimation, socialization of } \\
\text { newcomers }\end{array}$ \\
\hline \multirow{2}{*}{$\begin{array}{l}\text { Advantages and } \\
\text { disadvantages of } \\
\text { structures }\end{array}$} & $\begin{array}{l}\text { Efficiency in opportunism control and } \\
\text { information transfer; self-stabilization } \\
\text { within engaging of new members }\end{array}$ & $\begin{array}{l}\text { Efficiency in opportunism control and } \\
\text { uncertainty reduction }\end{array}$ \\
\hline & $\begin{array}{l}\text { Note: network communications may lead } \\
\text { to unprecedented deception (ref. } \\
\text { M.Granovetter examples) }\end{array}$ & $\begin{array}{l}\text { Note: institutional units are inactive, there's } \\
\text { a problem of pathdependence }\end{array}$ \\
\hline $\begin{array}{l}\text { Limits of structure } \\
\text { regulation scopes }\end{array}$ & Only network members & $\begin{array}{l}\text { Causes of actions and actors' preferences } \\
\text { are unpredictable. They can stand beyond } \\
\text { institutional regulation field }\end{array}$ \\
\hline Authority notion & $\begin{array}{l}\text { Authority is situational, it is determined by } \\
\text { participant's structural stand }\end{array}$ & $\begin{array}{l}\text { Authority is determined by the ability to } \\
\text { change control concepts }\end{array}$ \\
\hline Main principle & Flexibility & Confidence \\
\hline
\end{tabular}

\section{Conclusion}

Basic concepts of network and institutional approaches suggest that the network approach pays little attention the institutional structure that is a base of network relationships.

At the same time, the institutional approach does not adequately reflect the interaction of actors beyond the field of institutional regulation. The works of W. Baker and H.White (Baker, 1984, White, 1981) definition of concepts of cohesion and structural equivalence) substantiate that network influence lies in informal regulation and control. This allows overcoming uncertainties arising during the market crises. It helps to work quickly under the bounded rationality, ensuring stability and predictability.

Comparing this conclusion with the conclusion reasoned earlier within institutional approach on the TNC role as a risk-sharing facility, we come to understand the unity of scientific result and its justification within both institutional and network approaches. 
Thus, global network's activity on the world market results from its role of risk-sharing facility, on the one hand, and the role of informal market regulation during the market cataclysm associated with the reduction of formal regulatory institutions influence. The process of world economy transnationalization implies an increase of the network structures' number.

The activity of data network supranational a structure places a high value on the expansion of information technologies, involving the possibility to perform economic transactions. Relationships between network members are built on gathering and transmission of information, which determines the necessity of tracking and forming supply chains for the optimal quality of the network unit.

\section{References}

Alifanova, E. N. (2005). Institutional development of the Russian stock market in the context of financial globalization. RGEU (RINH), Rostov-on-Don, ISBN 5-7972-0744-3.

Baker, W. E. (1984). The Social Structure of National Securities Market. The American Journal of Sociology, 89(4), 775-811. http://dx.doi.org/10.1086/227944

Desai, M. A., Fritz, F. C., \& Forbes, K. J. (2014). Financial Constraints and Growth: Multinational and Local Firm Responses to Currency crises. NBER Working Paper No.w10545 Issued in June 2004 NBER Program(s). Retrieved March 11, 2014, from http://papers.nber.org/papers/W10545

Granovetter, M. (2002). Economical action and social structure: The problem of embeddedness. The American Journal of Sociology, 91(3), 481-510. http://dx.doi.org/10.1086/228311

Korolyov, I. S. (2003). World Economy: Global trends over 100 years (Ed.: Yurist, pp. 155-160). Moscow.

North, D. (1994). Evolution of efficient markets in history. Retrieved February 23, 2014, from http://dlc.dlib.indiana.edu/dlc/bitstream/handle/10535/4429/9411005.pdf? sequence=1

Oleinik, A. (2005). Institutional economic (p. 415). Infra-M, Moscow.

Sohrokov, T. H. (2011). Development of public services in a modern market economy. Ed. Economic Sciences. Retrieved July 16, 2014, from http://ecsocman.hse.ru/data/2012/08/10/1265221285/12.pdf

Stark, D. (1996). Recombined property and inception of Eastern European capitalism. Economics issues, University of Chicago, Retrieved February 23, 2014, from http:/www.thesenseofdissonance.com/ media/paper_recombinant_property.pdf

White, H. (1981). Where Do Markets Come from? American Journal of Sociology, 87. Retrieved July 16, 2014, from http://www.jstor.org/discover/10.2307/2778933?uid=2\&uid=4\&sid=21104497101163

Williamson, O. (1999). Production vertical integration: Speculations on market failing/ Marks of economical thought. Theory of consumer behavior and demand (Ed.: B. M. Galperin). Saint-Petersburg: Economic School. ISBN 5-900428-49-4.

World Development Indicators. (2013). Retrieved March 10, 2014, from http://data.worldbank.org/indicator/ NV.SRV.TETC.KD.ZG/countries?display=graph

\section{Copyrights}

Copyright for this article is retained by the author(s), with first publication rights granted to the journal.

This is an open-access article distributed under the terms and conditions of the Creative Commons Attribution license (http://creativecommons.org/licenses/by/3.0/). 